\title{
Ventrilectomia associada à cordectomia a laser em um equino de salto com hemiplegia laringea - relato de caso
}

Bruna Patricia Siqueira Raimundo; Matheus Dias Cunha, Julio Cesar Paganela, Carlos Eduardo Martins Veiga

Horse Center Laboratório e Clínica Veterinária, Petrópolis, RJ, Brasil

*Autor correspondente

e-mail: brunapsr@yahoo.com

\section{Resumo}

A hemiplegia laríngea é uma neuropatia que leva à degeneração do nervo laríngeo recorrente, resultando na atrofia dos músculos intrínsecos da laringe, que são inervados pelo mesmo. Com a paralisia da laringe, a abertura e fechamento das cartilagens aritenoides ficam comprometidas e provocam uma redução no lúmen da via aérea e do fluxo do ar, aumentando a resistência durante a inspiração, causando comprometimento das trocas gasosas em nível pulmonar, levando à queda de performance de cavalos atletas e causando um ruído respiratório durante a expiração, pelo deslocamento axial das cordas vocais. 0 diagnóstico é baseado nos sinais clínicos, onde é observado um chiado durante a inspiração, principalmente durante o exercício, além do histórico de intolerância ao exercício com queda de performance. A confirmação é feita através do exame de endoscopia das vias aéreas e observação da perda parcial ou completa da função abdutora na face afetada da laringe. 0 tratamento é cirúrgico, e embora o prognóstico seja reservado, há uma boa porcentagem de sucesso. Um equino, macho, 4 anos, Raça Brasileiro de Hipismo, utilizado em provas de salto, foi encaminhado à Clínica Horse Center com histórico de "roncar" durante o exercício. Ao exame de endoscopia em repouso, foi constada paralisia da aritenóide esquerda em grau III. 0 animal foi encaminhado para cirurgia, onde foi realizada a ventrilectomia com o objetivo de manter a cartilagem aritenóide afetada em abdução permanente, facilitando, assim, o fluxo de ar para os pulmões. No dia seguinte, com o animal em estação, realizou-se a cordectomia a laser a fim de aumentar o diâmetro ventral da rima da glote e minimizar o ruído respiratório durante o exercício. 0 animal recebeu alta no mesmo dia do procedimento e foi prescrito pós-operatório à base de antiinflamatório não esteroidal, antibioticoterapia e curativos locais à base de clorexidine a $2 \%$ e clorexidine hidroalcoólico, além de repouso por 30 dias. 0 retorno do animal para avaliação pós-cirúrgica foi feito em 60 dias. Segundo o proprietário, após a cirurgia o animal não apresentou ruídos respiratórios durante os exercícios e melhorou sua performance respiratória. Foi realizado exame de 
endoscopia, onde foi constado o sucesso da técnica de fixação da aritenoide. É descrito na literatura que a ventrilectomia por si só não é capaz de minimizar os ruídos respiratórios apresentados durante o exercício, fazendo-se necessária a utilização de outra técnica, que no caso, foi a de cordectomia a laser guiada por endoscópio. 0 uso do laser torna o procedimento simples e rápido, já que é um método seguro, que pode ser feito com o animal em estação, apenas com uso de sedativo, além de o tempo de recuperação do animal ser extremamente rápido. As técnicas associadas foram eficazes no tratamento da hemiplegia laríngea tanto na melhora da eficiência respiratória do animal, quanto na redução dos ruídos respiratórios, levando ao rápido retorno do animal para o desempenho da atividade esportiva.

Palavras-chave: Hemiplegia. Cavalo chiador. Laringe. 